\title{
A NOTE ON QASR SERIJ
}

\author{
By ST JOHN SIMPSON
}

Qasr Serij lies near an old route running along the southern foot of the Jabal al-Qusayr between Mosul and Nisibis (cf. Wilkinson, 1990: 50-51, Route B; Wilkinson, 1993: 552). As the name suggests, the site comprises the partly standing remains of a church originally dedicated to St Sergius, a popular eastern saint (Fiey, 1961). It has been identified as the stone church said to have been founded between 559-75 by one Mar Ahudemmeh at a spot known as Ain Qenoye or Ain Qena ('Spring of Reeds') in the vicinity of Balad (Eski Mosul) (Fiey, 1958). Preliminary descriptions, accompanied by the first known photographs of the ruins, were made by Gerald Reitlinger (1938: 148-49) and Aurel Stein (finally published in 1985: i, 105-107, Pl. 31c) following their respective surveys of medieval and Roman sites in the Jazira during the wet spring of 1938 (see also Lloyd, 1938: 136, No. 15; Ibrahim, 1986: 74, Site 211). In his subsequent study of the stillunexcavated ruins, David Oates (1962; 1968: 106-17, Pl. XIII) drew architectural parallels with fifth century and later churches in North Syria. Recently, in a series of important articles on early church architecture, Okada $(1990 ; 1991 ; 1992)$ has drawn attention to the contrast in plan and fittings of these basilica-type churches with Sasanian and Early Islamic churches in southern Mesopotamia, the Iraqi Western Desert and the Gulf.

A small amount of additional information is now available about Qasr Serij. Credit for its rediscovery should lie with the Danish explorer, Carsten Niebuhr. After several years of exploration in Arabia and Iran, Niebuhr returned to Europe via Baghdad. In the spring of 1766, en route from Mosul to Nisibis via Tell Hugna, he wrote the following description (Niebuhr, 1780: II, 307):

\footnotetext{
"A une demie lieuë au Sud de cette colline [i.e. T. Hugna], l'on voit encore sur une colline, un ancien édifice, que l'on nomme Kasr Scherridsch; mais il ne semble pas avoir été un chateau, comme le nom l'indique, mais peut-être une petite Eglise. Tout l'édifice n'est long, que de treize pas doubles et large de neuf, et entièrement bati de grandes pierres de taille; mais il est déja bien enforcé en terre. Je ne trouvois pas d'inscription icy, excepté les deux lignes $g$ Table XLIII sur une piérre, que se trouve détachée sur une muraille; je ne connois absolument pas ces Caractères. Ils ont beaucoup de rapport, avec ceux qu'IVES a copiés sur une colline entre l'Euphrate et Haleb."
}

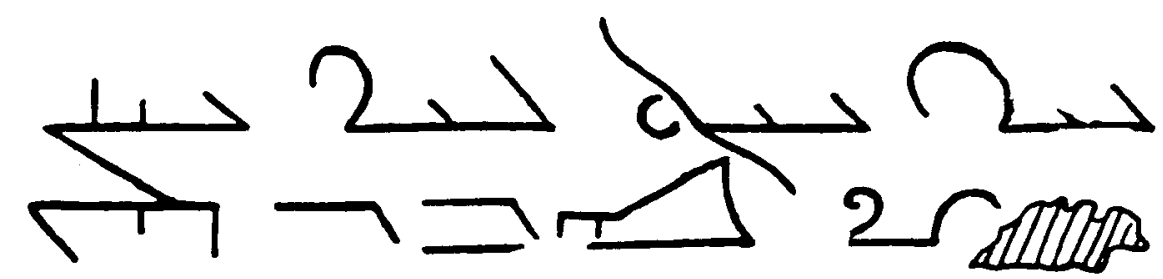

Fig. 1 Two-line Syriac inscription from Qasr Serij.

Most interesting was his discovery here of the fragmentary [Syriac] inscription cut into a stone block (Fig. 1; after Niebuhr, op. cit.: Table XLIII.g, facing p. 215). Dr Andrew Palmer has kindly suggested the following comments on it: the second half of the first line reads "to" or "by" John and the second line seems to end with "his son." If this interpretation is correct and if Niebuhr's inscription is complete, it must have taken the form of EITHER: [active verb] + John (accusative or dative) + [name of subject] + "his son" OR: [passive verb] + "by John" + "[and...] to his son", the subject here being the building into which the inscription was incorporated. The verb is uncertain (but cf. Palmer, 1988: 119). This inscription is no longer visible at the site and presumably has either been buried following further collapse of the structure or removed for re-use elsewhere. The continuing decay of the ruins can be judged through comparison of photographs published by Fiey (1958: Figs. 2-5) and Oates (1962: Pl. XXIX) with the situation today.

Little is known about the history of the site following references in 828 and 936; Fiey (1958: 127) doubted whether the church survived after the tenth century "because it was on the road of so many invaders." However, Oates (1962: 81) observed medieval or later alterations of the north aisle and 
apse; attention may also be drawn to traces of additional construction and re-modelling visible at the north-west exterior corner and southern exterior wall as a result of excavations evidently conducted by person (or persons) unknown subsequent to Oates' first visit (personal observation, 1987). Whereas the original construction was of good quality, diagonally dressed, limestone masonry, these modifications were made using a rubble and grey gypsum-mortar technique. Despite evidence for this type of construction at an earlier [Parthian] date in Iran, the earliest archaeological evidence for it within northern Iraq derives from medieval sites (e.g. Amin, 1987; cf. also Oates, 1956: 196). Indeed, Islamic and post-medieval handmade ceramics are found at Qasr Serij (personal observation) and the site is recorded also as fifteenth century (presumably on the basis of surface material) in the DGA Gazetteer of Sites and Excavations. Without excavation, however, it is impossible to ascertain whether this material was associated with a functioning church or whether it stems from later occupation perhaps accompanied by a change in function of the building. The name of the site suggests that in its latest phase the church may even have been re-used as a private residence. Excavations at the site of Museifneh, on the right bank of the Tigris within the Saddam Dam Salvage Project, provide a possible parallel for this. Here, a similar basilica-type masonry church, thought to be seventh century or earlier in date, was used and periodically restored until $c$. the twelfth century; the ruins were later re-used (Killick \& Roaf, 1983: 217; Nejim, 1987). ${ }^{1}$

A second church was partially excavated within this Project at the site of Khirbet Deir Situn (Curtis, 1989). ${ }^{2}$ This provides a further cautionary tale. On the basis of the present name ('the monastery with the [single] column'), Fiey (1965/68: II, 620-25) proposed that the site was that of a stylite foundation, possibly founded in 598 by one Mar Michael. Excavations were conducted here during $1985-86$ by a British Museum team, directed by Dr. J. E. Curtis. The remains of a rubble and gypsum-mortar church were discovered, with an important corpus of Late Sasanian ceramics and glassware sealed beneath the earliest floors. However, with the exception of a few small, worn and clearly residual sherds, all material found within and near the excavated building dated from the twelfth/thirteenth century onwards. ${ }^{3}$ The presence and whereabouts of the presumed Sasanian predecessor therefore remain uncertain but may reflect a pattern of foundation, decay and later re-foundation nearby. During a late - possibly post-medieval - phase the church underwent modifications in plan that suggest a change in function prior to eventual collapse and partial robbing during a final phase. Clay pipe fragments from the latest contexts allow a Late Ottoman dating for this phase, probably contemporaneous with a village on the nearby hillside.

Recent excavations in northern Iraq therefore provide archaeological evidence for a lengthier and more complex history of church development than hitherto suspected at Qasr Serij. The eventual destruction or abandonment of many of these buildings probably should be placed within the context of social change and Kurdish attacks during the Ottoman period, one that is vividly described by a number of early/mid nineteenth century European travellers (e.g. Forbes, 1839; Layard, 1849: I, 157, 166, 175, 184; Fletcher, 1850: I, 154-56, 248-49, 276, 321 ff, II, 31-32, 50-52; cf. also Fiey, 1975).

${ }^{1}$ The text of this report is partly ambiguous but may be
usefully summarised here. Four architectural phases were
recognised, some of which contained secondary building
sub-phases. The earliest phase (level 4 ), founded on natural
soil, comprised a pair of walls $1 \mathrm{~m}$ wide, $3.75 \mathrm{~m}$ apart and
running the full length of the eastern side of the phase 2
church. Their date and architectural context are unclear. The
second phase (level 3 ) was assigned to the ninth-tenth
centuries: parts of earlier construction were incorporated
with use of undressed masonry and gypsum plaster. The plan
is one of a basilical church enclosed in a square courtyard,
with further rooms on the eastern side and north-west
corner. The third phase (level 2 ), attributed to the eleventh-
twelfth centuries, was marked by further additions, block-
ings of certain arches and doorways, and the construction of
a semi-circular buttress against the downslope south-west
corner. Several bronze figural coins ( $544-652$ A.H.), moulded and barbotine ceramic plainwares belong to this phase. The fourth phase marks a change in plan, and possibly function, and was thought to date to the fourteenth century; the uppermost level (1) was characterised by walls up to a metre in height but without doorways, hence suggestive of sunken-floored crofts. Associated smokers' pipes date level 1 to the eighteenth century and later. Nearby tannurs were of similar date and may have been associated with the neighbouring village. I am indebted to Dr Luke Treadwell for kindly translating this report.

${ }^{2}$ A brief note was also published by Ball \& Black (1987: 237).

${ }^{3}$ Surface sherding had failed to identify this early occupation, demonstrating the inadequacy of this technique at multi-period sites capped by the remains of substantial stone architecture, such as Eski Mosul and Tells Abu Wajnam and Hugna (cf. also Oates, 1956: 192). 


\section{Bibliography}

Amin, A., 1987. Excavations at Kharabuk. Researches on the antiquities of Saddam Dam basin salvage and other researches (Demirji, M. S., ed.), 79-100 (Arabic section). Baghdad: SOAH, Ministry of Information.

Ball, W. \& Black, J., 1987. Excavations in Iraq, 1985-86. Iraq 49, 231-51, Pl. XLVII.

Curtis, J., 1989. Case of the missing column. British Museum Society Bulletin 60 (Spring), 7-9.

Fiey, J. M., 1958. Identification of Qasr Serej. Sumer 14, 125-27, Figs. 1-5.

Fiey, J. M., 1961. Les Saints Serge de l'Iraq. Analecta Bollandiana 79, 102-14.

Fiey, J. M., 1965/68. Assyrie chrétienne. Beirut: Imprimerie Catholique; three volumes.

Fiey, J. M., 1975. Chrétiens syriaques sous les Mongols (Il-Khanat de Perse, XIIIe-XIVe s.). Louvain: Corpus Scriptorum Christianorum Orientalium, 362.

Fletcher, J. P., 1850. Narrative of a two years' residence at Nineveh, and travels in Mesopotamia, Assyria and Syria. London: Henry Colburn; two volumes.

Forbes, F., 1839. A Visit to the Sinjar Hills in 1838, with some account of the Sect of Yezidis, and of various places in the Mesopotamian Desert, between the Rivers Tigris and Khabur. JRGS 9, 409-39.

Ibrahim, J. K., 1986. Pre-Islamic settlement in Jazirah. Baghdad: SOAH, Ministry of Information.

Killick, R. \& Roaf, M., 1983. Excavations in Iraq, 1981-82. Iraq 45, 199-224.

Layard, A. H., 1849. Nineveh and its remains. London: John Murray; two volumes.

Lloyd, S., 1938. Some ancient sites in the Sinjar district. Iraq 5, 123-42.

Nejim, A., 1987. The excavations of the Mosul University at Imsefna. Researches. . (Demirji, M. S., ed.), 13355 (Arabic section). Baghdad: SOAH, Ministry of Information.

Niebuhr, C., 1776/80 Voyage en Arabie \& en d'autres Pays circonvoisins. Amsterdam/Utrecht: S. J. Baalde/ Barthelemy Wild; two volumes.

Oates, D., 1956. The Roman frontier in Northern Iraq. GeogJ 122: 2 (June), 190-99, Figs. 1-5.

Oates, D., 1962. Qasr Serij - A Sixth Century Basilica in Northern Iraq. Iraq 24, 78-89, Pls. XXVII-XXIX.

Oates, D., 1968. Studies in the Ancient History of Northern Iraq. London: OUP.

Okada, Y., 1990. Reconsideration of plaque-type crosses from Ain Sha'ia near Najaf. Al-Rafidan 11, 103-12.

Okada, Y., 1991. Early Christian architecture in the Iraqi south-western desert. Al-Rafidan 12, 71-83.

Okada, Y., 1992. Ain Sha'ia and the early Gulf churches: an architectural analogy. Al-Rafidan 13, 87-93.

Palmer, A., 1988. The Epigraphic Diction of Tur 'Abdin and Environs. Oriens Christianus 72, 114-23.

Reitlinger, G., 1938. Medieval antiquities west of Mosul. Iraq 5, 143-56, Pls. XXI-XXVI.

Stein, M. A., 1985. Limes Report (Gregory, S. \& Kennedy, D., eds.). Oxford: BAR International Series 272; two volumes.

Wilkinson, T. J., 1990. The Development of Settlement in the North Jazira between the 7th and 1st Millennia B.C. Iraq 52, 49-62.

Wilkinson, T. J., 1993. Linear hollows in the Jazira, Upper Mesopotamia. Antiquity 67: 256 (September), $548-62$. 